Yu.V. Batygin, E.A. Chaplygin, S.A. Shinderuk

\title{
EXPERIMENTAL INVESTIGATION OF THE CURRENT DISTRIBUTION ON THE SHEET BLANK SURFACE IN LINEAR TOOLS OF MAGNETIC-PULSED ATTRACTION
}

Purpose. The purpose of the present work consists in the characteristics experimental determination of the pulsed current transverse distribution on the surface of a sheet non-magnetic metal between the point contacts of the power source with different geometry of their connection under operating frequencies variation. Methodology. The measurements were carried out using methods based on the known positions of electromagnetism. The simulating low-voltage equipment was used, as well as highvoltage power sources with a high level of the stored energy. Numerical processing of the measurement results was carried out using standard programs from the "Wolfram Mathematica» package. Results. The space-temporal shapes of the pulsed current density transverse distribution on the surface of the sheet blank were obtained and analyzed. It is established that the degree of transverse current concentration in sheet metal relative to the center of the system in the operating frequency range of $\sim 1.8 . . .22$ $\mathrm{kHz}$ depends very little on its temporal characteristics. It was found that the level of the transverse current concentration in the conditionally allocated band connecting the contacts of connection depends significantly on the ratio of the width of this band and the transverse dimensions of the contact connection. Moreover, the smallest current is concentrated in a strip whose width is much less than the distance between the contacts $(\leq 11 \ldots 16 \%)$. Originality. For the first time, the numerical estimates degree of the current transverse concentration are obtained and the dependence of this parameter on the temporal characteristics of the current, as well as on the method of connecting the power source contacts, is established. Practical value. The research results will allow creating the new more efficient linear tools of magnetic-pulsed attraction of sheet metals, based on the force interaction of conductors with unidirectional currents. References 10, tables 1, figures 7.

Key words: measurement of the current space-temporal distribution, sheet metal, linear tool, magnetic-pulsed attraction, Rogowski coil.

Метою роботи с експериментальне визначення характеристик поперечного розподілу щільності імпульсних струмів різної частоти на поверхні листового немагнітного металу між точковими контактами джерела потужності при різній геометрії їх підключення. Методика. Виміри проводилися за допомогою методів, заснованих на відомих положення електромагнетизму. Використовувалося модельне низьковольтне обладнання, а також високовольтні джсерела потужності з високим рівнем енергї̈, щчо запасається. Чисельна обробка результатів вимірювань проводилася за допомогою стандартних програм 3 пакету «Wolfram Mathematica». Результати. Отримано $i$ проаналізовано просторово-часові форми поперечного розподілу щільності імпульсного струму на поверхні листової заготовки. Наукова новизна. Вперще отримано чисельні оцінки ступеня поперечної концентрації струму $i$ встановлено залежність даного параметру від часових характеристик струму, а також від способу підключення контактів джерела потужності. Практичне значення. Результати досліджень дозволяють створювати нові більш ефективні лінійні інструменти магнітно-імпульсного притягання листових металів, щңо засновані на силовій взаємодї̈ провідників з односпрямованими струмами. Бібл. 10, табл. 1, рис. 7.

Ключові слова: вимірювання просторово-часового розподілу струмів, листовий метал, лінійний інструмент, магнітноімпульсне притягання, пояс Роговського.

Целью работы является экспериментальное определение характеристик поперечного распределения плотности импульсных токов разной частоты на поверхности листового немагнитного металла межсду точечными контактами источника мощности при различной геометрии их подключения. Методика. Измерения проводились с помощью методов, основанных на известных положениях электромагнетизма. Использовалось модельное низковольтное оборудование, а также высоковольтные источники мощности с высоким уровнем запасаемой энергии. Численная обработка результатов измерений проводилась с помощью стандартных программ из пакета «Wоlfram Mathematica». Результаты. Получены и проанализированы пространственно-временные формы поперечного распределения плотности импульсного тока на поверхности листовой заготовки. Научная новизна. Впервые получены численные оценки степени поперечной концентрации тока и установлена зависимость данного параметра от временных характеристик тока, а также от способа подключения контактов источника мощности. Практическое значение. Результаты исследований позволяют создавать новые более эффективные линейные инструменты магнитно-импульсного притяжения листовых металлов, основанные на силовом взаимодействии проводников с однонаправленными токами. Библ. 10, табл. 1, рис. 7.

Ключевые слова: измерение пространственно-временного распределения токов, листовой металл, линейный инструмент, магнитно-импульсное притяжение, пояс Роговского.

Introduction. The technique of high pulsed currents and their magnetic fields is increasingly used in modern industrial technologies for metal forming [1]. This fact is due to the appearance of new alloys with high strength characteristics and low density. As follows from production practice, the established traditional schemes and the corresponding equipment do not allow, for example, the molding of products from many aluminumbased alloys. An obstacle to the successful implementation of traditional technology is the destruction of the formed samples, since the required

(C) Yu.V. Batygin, E.A. Chaplygin, S.A. Shinderuk 
forces significantly exceed the yield strength of their materials. The use of magnetic pulse metal processing (MPMP) methods solves this problem, since with a shortterm force action the allowable relative deformations increase significantly $[1,2]$. Tools of technologies of this type make it possible to practically realize efficient stamping of products from flat sheet conductors. Obviously, the amplitudes of the excited electrodynamic forces substantially depend on the spatio-temporal distribution of currents flowing in the metal of the object being processed [1]. This fact determines the relevance of the research topic.

A brief review of the literature. Separate attempts at practical testing of linear tools of magnetic-pulsed attraction of specified sections of sheet metals to remove dents in car body covers were first presented by the authors of publications [2, 3]. Continuation of work in this direction is described in research publication [4-6]. Here, for the first time, the theoretical foundations of the effectiveness of tools of this type [4] and technical solutions protected by patents for their design [5] were laid. The authors of [6] performed numerical estimates of the characteristics of magnetic-pulse attraction of metals with low electrical conductivity.

For clarity of the further discussion, we should dwell on the physics of processes in linear tools of magneticpulsed attraction, the principle of which is based on the force interaction of conductors with unidirectional currents [7]. Structurally, instruments of this type contain two geometrically parallel conductors connected to the discharge circuit of a high-voltage power source. One of the conductors is the main current lead (an analogue of the inductor in magnetic pulse processing of metals $[1,4])$, the second one is the section of sheet metal to be deformed. According to Ampere law, electrodynamic attraction forces arise between parallel conductors with unidirectional currents [7]. With hard mechanical fixation of the main current lead, the dent metal will be attracted to its working surface [2, 3].

A distinctive feature of the presented instruments of attraction is the presence of contact electrical connection of the sheet metal section to be deformed directly to the discharge circuit of a high-voltage power source. In this regard, the issue of the transverse distribution of currents flowing between the contacts of the connection on the surface of the object of power exposure is of particular importance.

The first quantitative estimates of the characteristics of the current density distribution function on the surface of a sheet metal sample between the connection contacts of a high-voltage power source were described in the author's patents [5]. The results of studies of similar issues aimed at creating effective tools for progressive magnetic-pulse technologies for the force processing of metals with different electrophysical characteristics are also presented in $[8,9]$.

In general, an analysis of well-known publications shows that the results of all previous works require further development.
We concretize the research task. So, the main indicator determining the effectiveness of the force interaction of parallel currents (one in the main current lead, the second on in the metal with a dent) is the degree of their «spreading» in the transverse direction. Obviously, if «spreading» is absent, there is a maximum force of attraction. Otherwise, its integral value decreases. In this regard, the solution of the problem of assessing the characteristics of the spatio-temporal distribution of currents in conductors is necessary to determine, first of all, the capabilities of the method proper, based on the force interaction of magnetic fields of unidirectional parallel currents.

The solution to this problem is possible by experimental evaluation using two different approaches. The first one involves the direct measurement of the surface distribution of the linear current density flowing between the contacts of the connected source. The second one is the measurement of currents flowing in the selected zones of the transverse distribution. The totality of the results of the first and second experimental approaches allows to establish the level of reliability of theoretical estimates.

The goal of the work is the experimental determination of the characteristics of the transverse distribution of the density of pulsed currents of different frequencies on the surface of a sheet of non-magnetic metal between the point contacts of a power source with different connection geometry.

Note that the methodology for conducting these experiments, measurement methods, and numerical processing of the obtained results using the Wolfram Mathematica standard software package were performed in accordance with the methodology and calculation algorithms described in $[2,3,7,10]$. in Fig. 1:

The equipment and the object of study are shown

1. The power source is a low voltage current pulse generator

2. Digital oscilloscope-PV6501.

3. The matching device is of cylindrical type, providing a decrease in the operating frequencies of the exciting current to values of $\sim 1.5 \ldots 2 \mathrm{kHz}$.

4. The object of study is a sample of sheet nonmagnetic steel $\sim(150 \times 150) \cdot 10^{-3} \mathrm{~m}$, thickness $\sim 2 \cdot 10^{-3} \mathrm{~m}$.

The transverse distribution of the linear current density was measured in the central part of the sheet metal by varying the operating frequencies of the flowing current and various distances between the source connection contacts.

Option No. 1, high-frequency signal. The operating frequency in pulse is $\sim 20 \mathrm{kHz}$. The distance between the contacts is $2 H=0.1 \mathrm{~m}$ and $2 H=0.02 \mathrm{~m}$.

Option No. 2, low-frequency signal. The operating frequency in pulse is $\sim 1.5 \ldots 2 \mathrm{kHz}$. The distance between the contacts is $2 H=0.1 \mathrm{~m}$ and $2 H=0.02 \mathrm{~m}$. The diameter of the connection contacts is $\sim 0.005 \mathrm{~m}$.

The measurement results are oscillograms of current pulses (Fig. 2). 


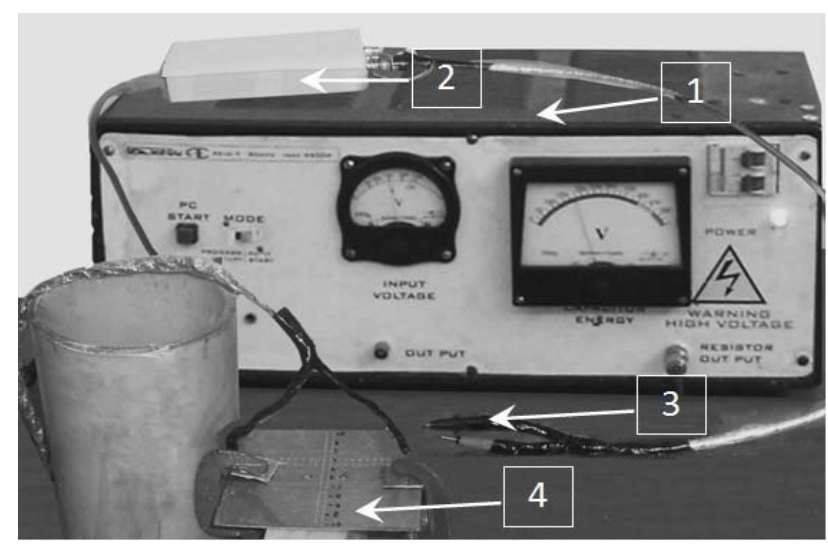

$a$

Electrical terminals To meter

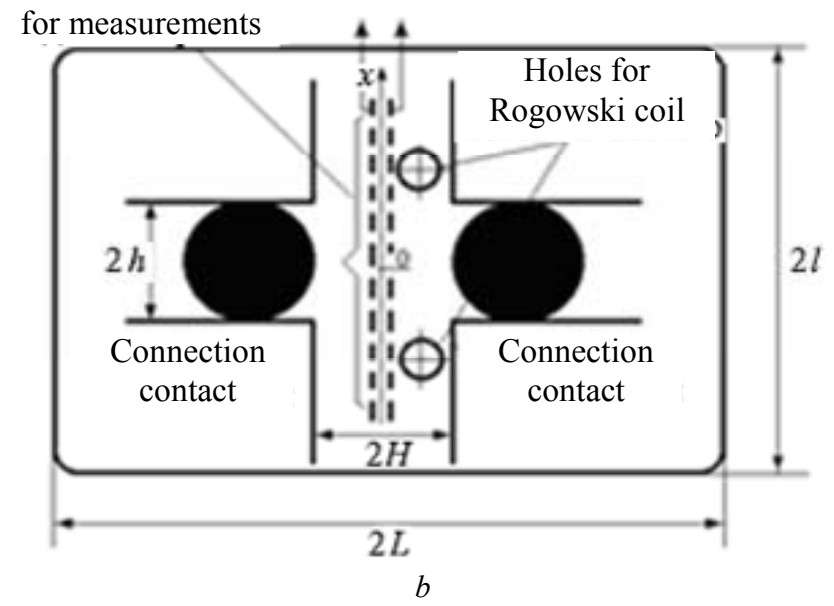

Fig. 1. Experimental equipment and the object of study: $a$-complex for modelling of electromagnetic processes in

MPMP: 1 - low-voltage current pulse generator,

2 - oscilloscope, 3 - measuring probes, 4 - sample of sheet nonmagnetic steel; $b$ - steel sample as an object of study in the adopted experimental scheme

The first thing that should be noted as a feature in the implementation of the experiment is a change in the temporal shape of the current pulse with a decrease in the operating frequency $(\sim 1.8 \mathrm{kHz}$, Fig. $2, c)$ in comparison with the signal frequency directly from the source $(\sim 21.1 \mathrm{kHz}$, Fig. $2, a)$. This circumstance is due to the influence of the matching device, which, in fact, is a pulse transformer with a primary multi-turn wire winding and a secondary single-turn winding in the form of a thin-walled aluminum cylinder with a longitudinal section. The current induced in a thinwalled metal, as shown by the authors [4], has the form of the time derivative of the current in the primary winding, which is actually illustrated by the oscillograms in Fig. 2, $a$ and Fig. 2,c.

We add that the measurement of the current supplied to the contacts was carried out by voltage oscillography on a low-inductance ohmic shunt connected in series in the source circuit with a load in the form of a sheet metal sample. Here there was an active, that is, directly proportional, connection between the voltage and the flowing current.

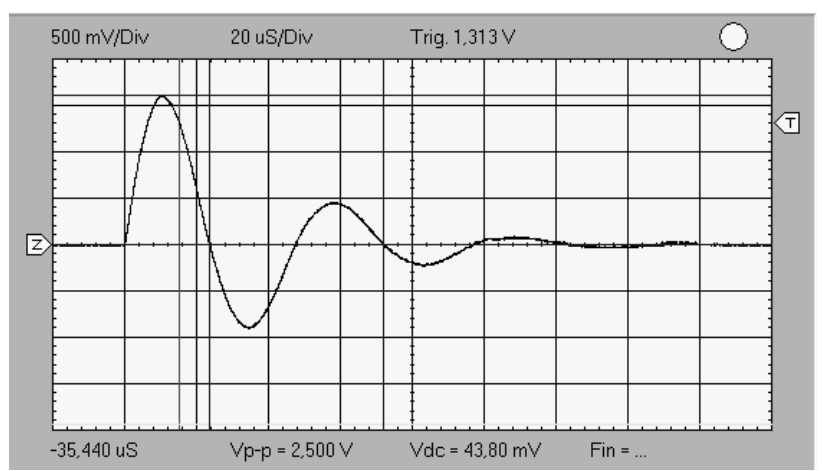

$a$
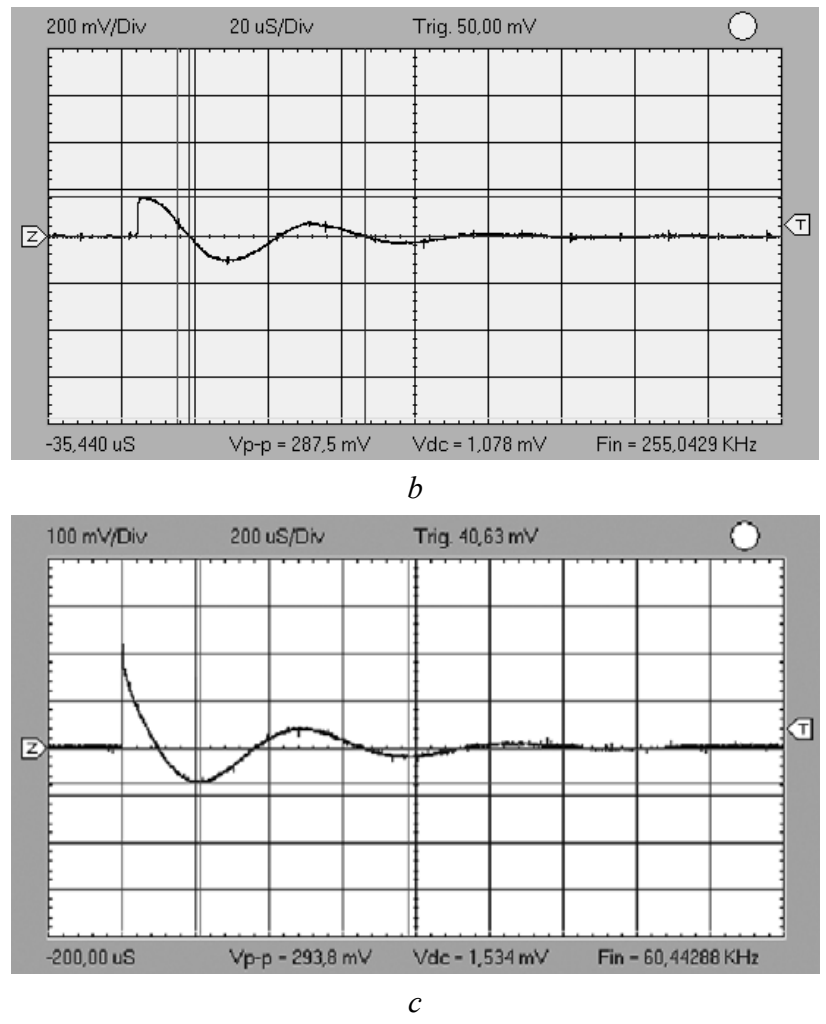

Fig. 2. Oscillograms of current pulses in the experiment: $a$ - signal supplied to the contacts, frequency $\sim 21.1 \mathrm{kHz}$; $b$ - signal taken from electrical terminals, frequency $\sim 21.1 \mathrm{kHz}$; $c$ - signal supplied to the contacts, frequency $\sim 1.8 \mathrm{kHz}$

Transverse distribution of linear current density. The measured signal was taken from the electrical terminals soldered into the sheet metal according to the geometry in Fig. 2,b. The results of measurements at various points were normalized to the central maximum. The final experimental data are presented in relative units (applicate axis) and are presented as graphical dependencies along the axial line between the source connection contacts (abscissa axis). The absolute abscissa coordinate $-\langle X\rangle$ is normalized to the distance between the source connection contacts, the relative abscissa coordinate $-x_{0}=(x / 2 H)$ (Fig. 3-6).

Option No. 1, high-frequency signal, $f=21.1 \mathrm{kHz}$. 


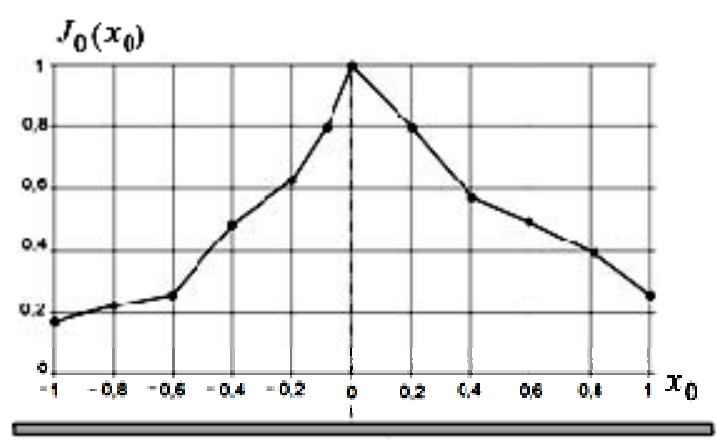

Fig. 3. Linear current density distribution in relative units (normalization to maximum) at $f=21.1 \mathrm{kHz}, 2 H=0.1 \mathrm{~m}$

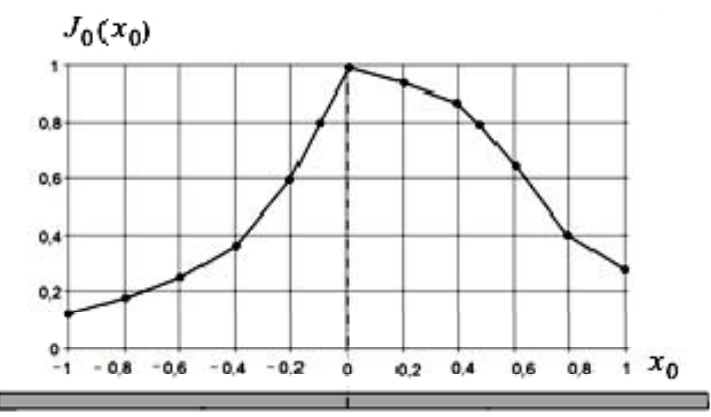

Fig. 4. Linear current density distribution in relative units (normalization to maximum) at $f=21.1 \mathrm{kHz}, 2 H=0.02 \mathrm{~m}$

Option No. 2, low-frequency signal, $f=1.8 \mathrm{kHz}$.

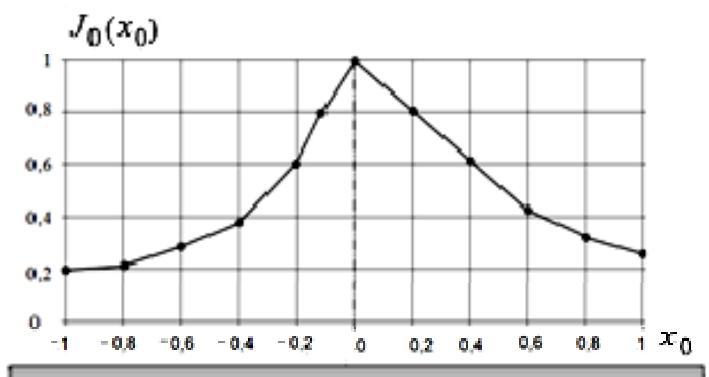

Fig. 5. Linear current density distribution in relative units (normalization to maximum) at $f=1.8 \mathrm{kHz}, 2 H=0.1 \mathrm{~m}$

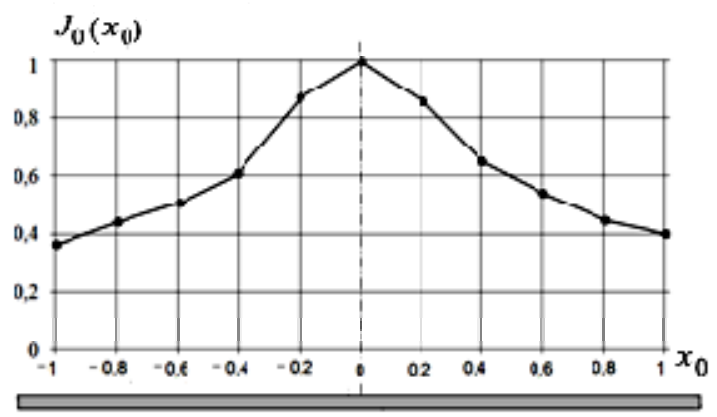

Fig. 6. Linear current density distribution in relative units (normalization to maximum) at $f=1.8 \mathrm{kHz}, 2 H=0.02 \mathrm{~m}$

Graphic illustrations of the investigated electromagnetic processes should be supplemented by numerical estimates of the degree of current concentration in the transverse dimension. We denote this indicator by $\eta$ and define it as the ratio of the corresponding areas of curvilinear trapezoids (certain integrals)

$$
\eta=\frac{S_{l}}{S_{L}} \cdot 100 \%,
$$

where $S_{l}$ is the area of the curved trapezoid with the base equal to $l$ ( $l$ is the length of the selected zone where the current concentration is determined), $S_{L}$ is the area of the curved trapezoid with the largest base $L=2 H$.

The calculation results are summarized in Table 1.

Table 1

Degree of current concentration in the selected zone

\begin{tabular}{|c|c|c|c|c|c|}
\hline \multirow[b]{2}{*}{ No. } & \multirow{2}{*}{$\begin{array}{r}\begin{array}{r}\text { Process } \\
\text { characte- } \\
\text { ristics }\end{array} \\
\begin{array}{l}\text { Distance } \\
\text { between } \\
\text { contacts }\end{array}\end{array}$} & \multicolumn{2}{|c|}{$\begin{array}{l}\text { Frequency } \\
f=21 \mathrm{kHz}\end{array}$} & \multicolumn{2}{|c|}{$\begin{array}{l}\text { Frequency } \\
f=1.8 \mathrm{kHz}\end{array}$} \\
\hline & & 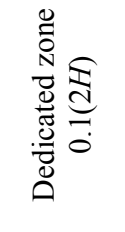 & 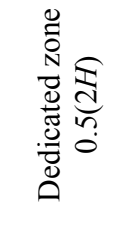 & 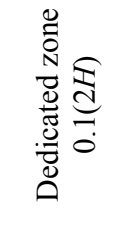 & 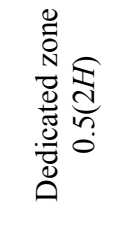 \\
\hline 1 & $2 H=0.1 \mathrm{~m}$ & $\eta=11 \%$ & $\eta=65 \%$ & $\eta=12 \%$ & $\eta=56 \%$ \\
\hline 2 & $2 H=0.02 \mathrm{~m}$ & $\eta=9 \%$ & $\eta=71 \%$ & $\eta=8 \%$ & $\eta=63 \%$ \\
\hline
\end{tabular}

A dedicated zone is a section whose center coincides with the reference point on the abscissa axis in the graph of the transverse distribution of the linear current density.

The generalization of the data given in Table 1 shows that in the studied system the degree of transverse concentration of current is determined mainly by the length of the dedicated zone $l$. For example, in the zone with $l=0.1(2 H)$, which, to a first approximation, is much less than the distance between the contacts, on average and regardless of the frequency, $\sim 10 \%$ of the flowing current is concentrated. In the zone with $l=1.0(2 \mathrm{H})$ equal to the distance between the contacts, again, on average and regardless of the frequency, $\sim 60 \ldots 65 \%$ of the flowing current is concentrated, $30 \ldots 35 \%$ of its integral value flows outside this zone.

In general, the analysis of the results of measurements of the transverse distribution of current density revealed the following patterns:

1. Regardless of the temporal parameters of electromagnetic processes, the distance between the contacts has a significant effect on the shape of the transverse distribution of the linear current density flowing between them.

2. As the distance decreases, the distribution becomes more «gentle» (closer to «rectangular»), the maximum value in the center is not pronounced.

3. With an increase in the distance between the contacts, the distribution takes on a «triangular» shape with a pronounced central maximum.

4. When lowering the frequency of the signal in the pulse (regardless of the distance between the contacts of the power supply connection), there is a more intense current spreading across the width of the sheet sample. This fact can be explained by comparing the current distribution over the cross section of the conductor in two limiting physical idealizations. In the case of the skin 
effect (ultrahigh frequencies), the current tends to stretch out in a line between the contacts. For direct current (ultra-low frequencies) there is a uniform distribution over the entire volume of the conductor.

5. The degree of concentration of the flowing current relative to the center of the system weakly depends on its temporal characteristics and is determined mainly by the transverse dimensions of the zone where its concentration is considered. Out of the zone with a length equal to the distance between the source connection contacts, about a third of the total current coming into the system flows.

We supplement the obtained results with measurements of the integrated characteristics of current distribution under conditions of connecting a real power source - a high-voltage magnetic-pulse installation.

Model measurements of the linear current density on the surface of the sheet sample illustrated the functional relationships of the degree of concentration of the flowing current and the size of the zone on the transverse axis between the contacts. However, the final quantitative estimates obtained by numerical processing of the results of model experiments require confirmation in real-life conditions of the operation of the tool of magnetic-pulse attraction, when the working currents are tens of thousands of Amperes.

Measuring complex and its features:

1. The measurements were carried out using a Rogowski coil, covering a conductor (sheet sample) with a measured current.

2. The main characteristic of the Rogowski coil is its so-called constant (allows to recalculate the EMF induced in the turns of the coil into a real current flowing through the conductor) - it was $G=13 \mathrm{kA} / \mathrm{V}$.

3. Through the integrating chain (integrator), the Rogowski coil is connected to a pulsed oscilloscope. Schematically, the measurements are illustrated by the graphics in Fig. 7.

4. According to the oscillograms, the EMF was measured in the Rogowski coil, after which the current in the conductor was determined using the coil's constant.

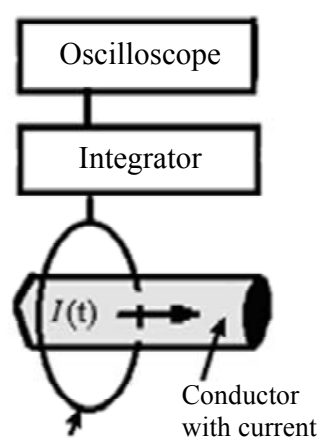

Rogowski coil

a

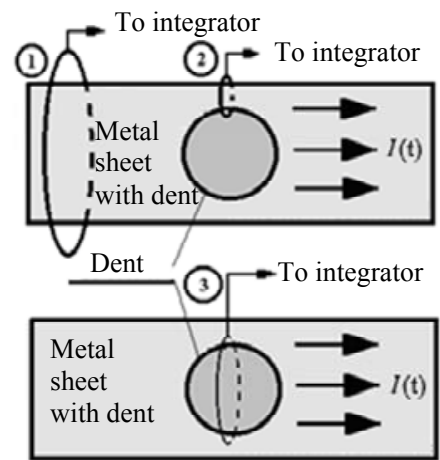

$b$
Fig. 7. Schemes for measurement of currents in the experiment: $a$-current measurement in an arbitrary conductor using the Rogowski coil; $b$ - measurement of currents in sheet metal with a dent

The experiments were conducted on the basis of the power equipment of the Department of Engineering Electrophysics of National Technical University «Kharkiv
Polytechnic Institute» (NTU «KhPI») under the agreement on scientific and technical cooperation between the Department of Physics of Kharkiv National Automobile and Highway University and the Department of Engineering Electrophysics of NTU «KhPI».

\section{Measurements. Results:}

1. The measurements were carried out in the operating mode of a magnetic pulse installation with stored energy of $10 \mathrm{~kJ}$ - MIU-10 (developed by NTU «KhPI») with working voltage on a capacitive storage $U=5.5 \mathrm{kV}$ and operating frequency of the current in the pulse of $\sim 6.75 \mathrm{kHz}$.

2. The distance between the contacts of the power source connection to the sheet sample was $\sim 0.1 \mathrm{~m}$.

3. The sheet sample in the transverse direction is divided into sections of equal width: 1 - the whole sample, $2-$ sections outside the dent $(\sim 1 / 3$ of the sample width), 3 - section with the dent $(\sim 1 / 3$ of the sample width).

4. Currents in sheet metal (in sections) $-I_{1}, I_{2}, I_{3}$ were measured using the Rogowski coil according to the diagram in Fig. 7,a.

Measurement results. According to the dedicated zones on sheet metal $-I_{1}=32.5 \mathrm{kA}, I_{2}=14.3 \mathrm{kA}$, $I_{3}=7.8 \mathrm{kA}$.

Total current in a sheet sample:

- summation of measurement results:

$$
I_{1-\text { calc }}=2 I_{2}+I_{3}=36.4 \mathrm{kA} \text {; }
$$

- direct measurement:

$$
I_{1 \text {-meas }} \approx 32.5 \mathrm{kA} \text {. }
$$

The reliability level of the measurement results, determined by the discrepancy between the calculation and measurement data ( $I_{1 \text {-calc }}$ and $\left.I_{1 \text {-meas }}\right)$, does not exceed $\sim 12 \%$, which is quite acceptable for the practice of MPMP $[1,4]$.

The ratio of currents in the dent and in the blank (concentration index): $\eta=I_{3} / I_{1}=7.8 / 32.5=24 \%$.

Note that a similar value in model experiments, averaged over frequencies, does not exceed $30 \%$.

In general, measurements of current distribution on the surface of a sheet sample, carried out under real conditions of connection to a high-voltage power source, did not reveal significant deviations in the assessment of the degree of concentration of the flowing current as a function of the dedicated size of the zone along the transverse axis between the contacts from the results of model experiments.

\section{Conclusions.}

1. It is found that the degree of transverse concentration of current in sheet metal relative to the center of the system in the range of operating frequencies $\sim 1.8 \ldots 22 \mathrm{kHz}$ very weakly depends on its temporal characteristics.

2. It is substantiated that the level of the transverse concentration of current in a conventionally allocated strip connecting the connection contacts substantially depends on the ratio of the width of this strip and the transverse dimensions of the contact connection. The smallest current is concentrated in a strip whose width is much less than the distance between the contacts $(\leq 11 \ldots 16 \%)$. 
3. It is shown that when the distance between the contacts connecting the source decreases, the degree of concentration of the transverse current flow increases. With a sufficiently small distance (approximately equal to the width of the actual contacts), the concentration level can reach values of $\sim 65 \ldots 80 \%$.

4. For the first time, experimentally substantiated results of a numerical estimation of the degree of transverse concentration of current on the surface of a sheet blank in linear tools of magnetic pulse attraction are obtained, the dependence of this parameter on the temporal characteristics of the current, as well as on the method of connecting the contacts of the power source is determined, which allows to create new, more efficient linear tools of magnetic-pulse attraction of sheet metals, based on the force interaction of conductors with unidirectional currents.

\section{REFERENCES}

1. Psyk V., Risch D., Kinsey B.L., Tekkaya A.E., Kleiner M. Electromagnetic forming - A review. Journal of Materials Processing Technology, 2011, vol. 211, no. 5, pp. 787-829. doi: 10.1016/j.jmatprotec.2010.12.012.

2. Bondarenko A.Y., Finkelshtein V.B., Stepanov A.A. Experimental approbation of an electrodynamic direct electric system for external automobile body repair. Electrical engineering \& electromechanics, 2014, no. 4, pp. 50-52. (Rus). doi: 10.20998/2074-272X.2014.4.09.

3. Bondarenko A.Yu., Finkelishteyn V.B., Gavrilova T.V External straightening basket of the motor transport by means of electro dynamic of the systems at direct drive pulsed current. Bulletin of NTU «KhPI». Series: Car- and tractorbuilding, 2014, no. 9 (1052), pp. 66-72. (Rus).

4. Batygin Yu., Barbashova M., Sabokar O. Electromagnetic metal forming for advanced processing technologies. Springer International Publ. AG, 2018. 93 p. doi: 10.1007/978-3-31974570-1.

5. Batygin Yu.V., Chaplygin E.A., Shinderuk S.A., Strelnikova V.A. The main inventions for technologies of the magnetic-

How to cite this article:

Batygin Yu.V., Chaplygin E.A., Shinderuk S.A. Experimental investigation of the current distribution on the sheet blank surface in linear tools of magnetic-pulsed attraction. Electrical engineering \& electromechanics, 2020, no.2, pp. 46-51. doi: 10.20998/2074-272X.2020.2.07. pulsed attraction of the sheet metals. A brief review. Electrical engineering \& electromechanics, 2018, no. 3, pp. 43-52. doi: 10.20998/2074-272X.2018.3.06.

6. Batygin Yu.V., Chaplygin E.A., Shinderuk S.A., Strelnikova V.A. Numerical estimates of currents and forces in linear tools conductance metals. Electrical engineering \& electromechanics, 2019, no. 5, pp. 40-44. doi: 10.20998/2074-272X.2019.5.07.

7. Griffiths D.J. Introduction to Electrodynamics. 4th Edition. Cambridge University Press. United Kingdom, 2017. 620 p.

8. Batygin Yu.V., Chaplygin E.A., Shinderuk S.A. Calculation of fields and currents in the induction system with the attractive screen and the additional coil as a tool for the straightening. Electrical engineering \& electromechanics, 2015, no. 1, pp. 57 62. (Rus). doi: 10.20998/2074-272X.2015.1.11.

9. Imbert J.M., Winkler S.L., Worswick M.J., Olivera D.A., Golovashchenko S. The effect of tool-sheet interaction on damage evolution in electromagnetic forming of aluminum alloy sheet. Journal of Engineering Materials and Technology, 2005, vol. 127, no.1, pp. 145-153. doi: 10.1115/1.1839212.

10. Gnatov A., Argun S., Ulyanets O. Joint innovative double degree master program «Energy-saving technologies in transport». 2017 IEEE First Ukraine Conference on Electrical and Computer Engineering (UKRCON), May 2017. doi:

Received 04.07.2019

Yu.V. Batygin ${ }^{1}$, Doctor of Technical Science, Professor, E.A. Chaplygin ${ }^{1}$, Candidate of Technical Science, Associate Professor,

S.A. Shinderuk ${ }^{1}$, Candidate of Technical Science, Associate Professor,

${ }^{1}$ Kharkiv National Automobile and Highway University, 25, Yaroslava Mudrogo Str., Kharkov, 61002, Ukraine, phone +380 577003852 ,

e-mail: yu.v.batygin@gmail.com; chaplygin.e.a@gmail.com; s.shinderuk.2016102@ukr.net of the magnetic-pulse attraction of metals. Part 1: Low electrical 10.1109/ukrcon.2017.8100442. 